\title{
Estrogen receptor- $\alpha$ gene (T/C) Pvu II polymorphism in endometriosis and uterine fibroids
}

\author{
Sujatha Govindan ${ }^{\mathrm{a}, \mathrm{b}}$, Noor Ahmad Shaik ${ }^{\mathrm{a}, \mathrm{c}, \mathrm{e}}$, Bhavani Vedicherla ${ }^{\mathrm{a}}$, Vijayalakshmi Kodati ${ }^{\mathrm{a}}$, \\ Kaipa Prabhakar Rao ${ }^{\mathrm{c}}$ and Qurratulain Hasan ${ }^{\mathrm{a}, \mathrm{b}, \mathrm{d}, *}$ \\ ${ }^{a}$ Department of Genetics, Vasavi Medical and Research Centre, Khairtabad, Hyderabad-500 004, Andhra Pradesh, \\ India \\ ${ }^{\mathrm{b}}$ Department of Genetics, Bhagwan Mahavir Medical Research Centre, A.C. Guards, Hyderabad-500 004, Andhra \\ Pradesh, India \\ ${ }^{\mathrm{c}}$ Department of Genetics, University College of Science, Osmania University, Hyderabad-500 007, Andhra \\ Pradesh, India \\ ${ }^{\mathrm{d}}$ Department of Genetics and Molecular Medicine, Kamineni Hospitals, L.B. Nagar, Hyderabad-500 044, Andhra \\ Pradesh, India \\ ${ }^{\mathrm{e}}$ Biomarkers Research Centre, Department of Biochemistry, King Saud University, Riyadh-11451, Saudi Arabia
}

\begin{abstract}
Endometriosis and fibroids are estrogen-dependent benign pathologies of the uterus, which account for infertility and pelvic pain along with dysmenorrhea in women. Suppression of the disease and recurrence after discontinuing hormone therapy strongly suggests that these are responsive to hormones, especially estrogen, which acts via its receptor. A T/C SNP in intron 1 and exon 2 boundary of estrogen receptor (ER) $\alpha$ gene recognized by PvuII enzyme has been associated with several female pathologies like breast cancer, osteoporosis, endometriosis and fibroids in various ethnic groups. The aim of the present study was to assess this $\mathrm{ER} \alpha \mathrm{T} / \mathrm{C}$ polymorphism in endometriosis and fibroid patients from Asian Indian population. Genomic DNA was isolated from 367 women, who included 110 cases of endometriosis, 142 cases of uterine fibroids and 115 healthy age matched women volunteers. PCR was carried out to amplify ER $\alpha$ gene followed by restriction digestion with Pvu II. Results indicate a significant association of $\mathrm{C}$ allele with both endometriosis $[\mathrm{OR}=2.6667,95 \% \mathrm{CI}=1.4166$ to $5.0199 ; p<0.05]$ and fibroids [2.0833, 95\% $\mathrm{CI}=1.1327$ to $3.8319 ; p<0.05]$. Further studies are needed in larger population to establish ER $\alpha \mathrm{C}$ allele as a risk marker for endometriosis and fibroids in Asian Indian women. Ethnicity, race, diet etc may play a role in susceptibility to endometriosis and fibroids and further studies are warranted in this area.
\end{abstract}

Keywords: Estrogen receptor, Pvu II polymorphism, Intron 1, endometriosis, fibroids

\section{Introduction}

Estrogen is a steroid hormone, which plays a major role in female physiology and pathology. It regulates

* Corresponding author: Dr. Q. Hasan, Research Advisor, Dept of Genetics \& Molecular Medicine, Vasavi Medical and Research Centre, Hyderabad-500004, India. Tel.: +91 4023210251 ; Fax: +91 40 66107930; E-mail: qhasan2000@yahoo.com. the normal physiological aspects of ovulation and menstruation, but its altered regulation promotes various benign and malignant uterine pathologies. Endometriosis and fibroids are two such estrogen-dependent benign growths, which account for infertility and pelvic pain along with dysmenorrhea. Surgical procedures and hormonal therapy like administration of anti-estrogens and GnRH agonists are the major available treatment options. Suppression of the disease and recurrence after discontinuing hormone therapy strongly suggests 
that these are responsive to hormones, especially estrogen [1-3]. Obesity, early onset of menarche and unopposed estrogen exposure due to nulliparity have been linked to an increased risk for both these pathologies, while use of oral contraceptives and pregnancy have been identified as protective factors [4-7].

Both physiological/pathological activities of estrogens are mediated via estrogen receptor (ER), which has two isoforms $\operatorname{ER} \alpha$ and $\operatorname{ER} \beta$, that are encoded by two different genes. Although both the isoforms of ERs differ in their structure they share a considerable homology in the DNA and ligand-binding domains. Both ER isoforms express in osteoblasts, osteoclasts, bone marrow and uterus. Studies using hormoneligand binding assays, immunohistochemistry, reverse transcription-polymerase chain reaction and in situ hybridization have shown altered expression of ER in different pathologies [8-12].

Since the discovery that allelic variants of the genes encoding for ER are associated with altered expression of sex steroid-responsive systems, the polymorphisms of these genes have been postulated as candidate risk markers for a number of female pathologies [13,14]. The ER $\alpha$ gene/ ESRl located on chromosome 6q25 has 8 exons and spans over more than 140-kilo bases. A T/C SNP in intron 1 and exon 2 boundary of ER recognized by the enzyme, PvuII has been studied in breast cancer, osteoporosis, endometriosis and fibroids in various ethnic groups [14-23]. Since, there are no studies to date on the role of ER $\alpha$ PvuII polymorphism (rs2234693) in the susceptibility of endometriosis and fibroids in Asian Indian population; we have evaluated its association with these two pathologies.

\section{Materials and methods}

\subsection{Sampling}

The present study was carried out on 367 women which included 110 cases of endometriosis, 142 cases of uterine fibroids and 115 healthy age and sex matched controls who visited the Gynecology Unit for routine check up. The subjects were recruited from three hospitals located in the cosmopolitan city of Hyderabad, in South India after thorough clinical examination and confirmatory diagnosis by ultrasound scan, laproscopy and laprotomy by experienced gynecologists. $2 \mathrm{ml}$ of peripheral blood was collected from all the individuals after obtaining detailed information about clinical, menstrual, obstetric history including age at menar- che, duration of cycles, use of contraceptives, treatment methods etc., This study was approved by the institutional ethics committee. Informed consent was obtained from all the participants of this study.

\section{DNA isolation and PCR}

Genomic DNA was isolated from all the blood samples using salting out method, which is routinely done in our laboratory [24]. The DNA was stored at $-20^{\circ} \mathrm{C}$ until PCR was carried out. A three step PCR with annealing at $60^{\circ} \mathrm{C}$ was carried out in a thermal cycler (Eppendorf, Germany) with $25 \mu \mathrm{l}$ reaction volume as described previously [25], using specific published primers synthesized at Bioserve Biotechnologies Ltd (Hyderabad, India) for intron 1 - exon 2 region of ER $\alpha$ gene [17].

Primer sequence:

Forward: 5' AGG GTT ATG TGG CAA TGA CG 3' Reverse: 5' CCT GCA CCA GAA TAT GTT ACC T $3^{\prime}$

Genotyping for ER- $\alpha$ Pvu II (T/C) polymorphism: The amplicon obtained was $1374 \mathrm{bp}$, upon restriction digestion with Pvu II (Fermentas Life Sciences, Canada) and agarose gel electrophoresis, 937 and $437 \mathrm{bps}$ bands indicated the presence of $\mathrm{T}$ allele, while abrogated restriction site giving the same 1374 bp band indicated $\mathrm{C}$ allele.

Statistical analysis: $\mathrm{X}^{2}$ test was done to compare the expected and observed frequencies of categorical variables. Odds ratio test was used to assess the strength of association of genotype and allele frequency and risk of disease occurrence.

\section{Results}

Out of 110 cases of endometriosis, $66.36 \%$ were homozygous for $\mathrm{C}$ allele, $29.09 \%$ were heterozygous and $4.5 \%$ were homozygous for $\mathrm{T}$ allele with the frequencies of $\mathrm{C}$ and $\mathrm{T}$ alleles being 0.81 and 0.19 , respectively. Among 142 cases of uterine fibroids $60.56 \%$ were homozygous for $\mathrm{C}$ allele, $30.28 \%$ were heterozygous and $9.15 \%$ were homozygous for $\mathrm{T}$ allele with frequencies of $\mathrm{C}$ and $\mathrm{T}$ alleles being 0.76 and 0.24 respectively. Among 115 controls, $46.95 \%$ were homozygous for $\mathrm{C}$ allele and $27.82 \%$ were heterozygous while $25.21 \%$ were homozygous for $\mathrm{T}$ allele with the frequencies of $\mathrm{C}$ and $\mathrm{T}$ allele being 0.61 and 0.39 respectively (Table 1). Allele frequencies were in Hardy-Weinberg equilibrium. 
Table 1

Genotype distributions of estrogen receptor (ER- $\alpha$ ) T/C Pvu II gene polymorphisms in endometriosis, fibroids and controls

\begin{tabular}{cccc}
\hline Genotype & $\begin{array}{c}\text { Endometriosis } \\
n=110\end{array}$ & $\begin{array}{c}\text { Fibroids } \\
n=142\end{array}$ & $\begin{array}{c}\text { Controls } \\
n=115\end{array}$ \\
\hline TT & $5(4.5 \%)$ & $13(9.15 \%)$ & $29(25.21 \%)$ \\
TC & $32(29.09 \%)$ & $43(30.28 \%)$ & $32(27.82 \%)$ \\
CC & $73(66.36 \%)$ & $86(60.56 \%)$ & $54(46.95 \%)$ \\
T Allele & 0.19 & 0.24 & 0.39 \\
C Allele & 0.81 & 0.76 & 0.61 \\
\hline
\end{tabular}

These results indicate a significant association of CC genotype with endometriosis [OR $=7.8407,95 \% \mathrm{CI}=$ 2.8495 to $21.575 ; p<0.05]$, and fibroids [3.5527,95\% $\mathrm{CI}=1.6994$ to $7.4271 ; \mathrm{p}<0.05]$. Statistical analysis carried out with different genotype models shows that $\mathrm{CC}$ vs TC+TT is significant indicating that $\mathrm{CC}$ genotype predisposes an individual to both these pathologies (Table 2).

\section{Discussion}

Benign uterine disorders like endometriosis and fibroids contribute to a significant amount of morbidity in women of reproductive age group. Endometriosis is characterized by the presence of tissue histologically similar to the endometrium at ectopic sites, while fibroids are myometrial growths of the uterine walls. Differential origin and physiological heterogeneity but similarity in the development, as well, as therapeutic response generates interest to understand the role of hormone receptors in their molecular pathogenesis. Additionally, studies revealing aberrant hormonal receptor expression in endometrial tissues and fibroid indicate their crucial role in these disorders [7,8]. Polymorphisms in the candidate genes like hormonal receptors, growth factors, cell cycle control genes, angiogenic factors and detoxifying genes has been studied in both these pathologies in different ethnicities, with contradictory results $[7,9,14,25-27]$. Though, genetic susceptibility of Indian women to both the pathologies has not been explored much, few studies reported the lack of association between gene polymorphisms of detoxification enzymes, hormone receptors and cytokines in endometriosis [25,28-30]. However, polymorphic (CAG)n repeats in Androgen Receptor (AR) gene were proposed as a high risk marker for both endometriosis and fibroids in Asian Indian women [31].

Studies suggested that ER $\alpha$ genetic variants confers differential susceptibility to individual disorders [14]. $\mathrm{ER} \alpha$ gene Pvu II polymorphism has been assessed in different ethnic groups with conflicting results in both endometriosis and uterine fibroids. 'C' allele was found to be significantly associated with endometriosis in Caucasian Greek, Asian Japanese and Asian Taiwanese women $[14,15,17]$, while no association was found in Caucasian German women [23]. With regards to fibroids this polymorphism was not found to be associated in Caucasians, where as significant association was observed in Asian Taiwanese, Americans and Hispanics [14,18,20,21]. Although a number of polymorphisms exist in ER $\alpha$ gene, Pvu II T/C has been reported to be associated with several pathologies of reproductive age group women, which indicates that this polymorphism is of significant importance, affecting the functionality of ER.

Most studies have reported their findings based on the perception that a Pvu II recognition sequence creating a restriction site generates the $\mathrm{C}$ allele and not $\mathrm{T}$ allele as we have assessed [32]. We found that the CAG/CTG region in the intron1-exon 2 junction of the $\mathrm{ER} \alpha$ when analyzed by the NEB cutter database (tools.neb.com/NEBcutter/index.php3), results in recognition by Pvu II if the $\mathrm{T}$ allele but not $\mathrm{C}$ alleles' is presence in the sequence. This indicates that there has been a great deal of misinterpretation of results in some studies, which has created confusion in literature regarding the frequency and significance of Pvu II polymorphism.

Reports published by Kitawaki et al. [17], Hseih et al. [14], Massart et al. [18] have reported ' $C$ ' allele as ' $\mathrm{T}$ ' allele, while results of Georgiou et al. [15] could not be evaluated as their study methodology was unclear. Studies on Caucasians including Italian and German women did not show any association of either alleles with both the pathologies [18,21]. Kitawaki et al. [17] reported that $\mathrm{C}$ allele is associated with both endometriosis and fibroids, however, re-assessment of their results indicates association of $\mathrm{T}$ allele and not $\mathrm{C}$ allele with the pathologies. However, this association was observed when compared to cervix cancer patients but was not observed when compared to their control population. Similar revision of data from Hseih et al. [14] showed that $\mathrm{T}$ but not $\mathrm{C}$ allele was associated with endometriosis and fibroids in Asian Taiwanese women. Contradictory to these findings, we observed that $\mathrm{C}$ allele is significantly associated with endometriosis and fibroids in Asian Indian population which may be attributed to ethnic differences. Table 3 represents the comparison of previous and present study results after revising the data according to the actual cleavage pattern of Pvu II.

Several hypothesis have been put forth to understand the functional significance of this polymorphism. Prob- 
Table 2

Analysis of genotypes and alleles among the two patient groups and controls

\begin{tabular}{lll}
\hline Genotype & $\begin{array}{l}\text { Endometriosis } v \text { control } \\
\text { Odd's Ratio; } \mathrm{X}^{2} \mathrm{p}\end{array}$ & $\begin{array}{l}\text { Fibroids } v s \text { controls } \\
\text { 0dd's Ratio; } \mathrm{X}^{2} \mathrm{p}\end{array}$ \\
\hline CC $v$ TC & NS* & NS* \\
CC $v s$ TT & $7.8407(95 \% \mathrm{CI}=2.8495$ to 21.575$) ; p<0.05$ & $3.5527(95 \% \mathrm{CI}=1.6994$ to 7.4271$) ; p<0.05$ \\
$\mathrm{TT} v s \mathrm{TC}$ & $0.1724(95 \% \mathrm{CI}=0.0593$ to 0.5017$) ; p<0.05$ & $0.3336(95 \% \mathrm{CI}=0.1501$ to 0.7412$) ; p<0.05$ \\
$\mathrm{CC} v s \mathrm{CT}+\mathrm{TT}$ & $2.2287(95 \% \mathrm{CI}=1.3$ to 3.8209$) ; p<0.05$ & $1.7348(95 \% \mathrm{CI}=1.055$ to 2.8527$) ; p<0.05$ \\
$\mathrm{C} v s$ T alleles & $2.6667(95 \% \mathrm{CI}=1.4166$ to 5.0199$) p<0.05$ & $2.0833(95 \% \mathrm{CI}=1.1327$ to 3.8319$) ; p<0.05$ \\
\hline
\end{tabular}

Table 3

Genotype and Allele frequency distribution of ER- $\alpha$ (T/C) polymorphism in different ethnic groups after correction of analysis criteria

\begin{tabular}{|c|c|c|c|c|c|c|c|}
\hline \multirow[t]{2}{*}{ Study } & \multirow[t]{2}{*}{ Ethnic group } & \multirow[t]{2}{*}{ Disease } & \multicolumn{3}{|c|}{ Genotype $(\%)$} & \multicolumn{2}{|c|}{ Allele frequency } \\
\hline & & & TT & TC & $\mathrm{CC}$ & $\mathrm{T}$ & $\mathrm{C}$ \\
\hline \multirow{2}{*}{$\begin{array}{l}\text { Kitawaki et al } \\
2001 \text { (17) }\end{array}$} & \multirow[t]{2}{*}{ Asian Japanese } & Endometriosis & 33 & 54 & 13 & 0.60 & 0.39 \\
\hline & & Adenomyosis and/ or Fibroids & 33 & 52 & 15 & 0.58 & 0.40 \\
\hline \multirow{2}{*}{$\begin{array}{l}\text { Massart et al } \\
2003 \text { (18) }\end{array}$} & \multirow[t]{2}{*}{ Caucasian Italian } & Uterine fibroids & 29.4 & 49.3 & 21.3 & 0.53 & 0.46 \\
\hline & & Control & 5.6 & 70.8 & 23.6 & 0.41 & 0.59 \\
\hline \multirow{5}{*}{$\begin{array}{l}\text { Renner et al } \\
2006(23) \\
\text { Hsieh et al } \\
2007 \text { (14) }\end{array}$} & \multirow[t]{2}{*}{ Caucasian German } & Endometriosis & 20.4 & 20.4 & 59.2 & 0.30 & 0.69 \\
\hline & & Control & 16.3 & 29.6 & 54.1 & 0.31 & 0.68 \\
\hline & \multirow[t]{3}{*}{ Asian Taiwanese } & Endometriosis & 15.2 & 60.7 & 24.1 & 0.45 & 0.54 \\
\hline & & Uterine fibroids & 5.6 & 70.8 & 23.6 & 0.41 & 0.59 \\
\hline & & Control & 5.5 & 40 & 54.5 & 0.54 & 0.47 \\
\hline \multirow{6}{*}{$\begin{array}{l}\text { Al-Hendy } \\
\text { et al } 2006(20)\end{array}$} & \multirow[t]{2}{*}{ American- Black, } & Uterine fibroids & 23.9 & 37 & 39 & 0.42 & 0.57 \\
\hline & & Control & 42.9 & 42.9 & 14.3 & 0.64 & 0.36 \\
\hline & \multirow[t]{2}{*}{ - White } & Uterine fibroids & 34.4 & 37.7 & 27.9 & 0.532 & 0.467 \\
\hline & & Control & 35.9 & 62.3 & 1.9 & 0.671 & 0.32 \\
\hline & \multirow[t]{2}{*}{ Hispanic women } & Uterine fibroids & 31.1 & 51.1 & 17.8 & 0.57 & 0.43 \\
\hline & & Control & 52.9 & 35.3 & 11.8 & 0.71 & 0.29 \\
\hline Denschlag & \multirow[t]{2}{*}{ Caucasian German } & Uterine fibroids & 25.4 & 50.8 & 23.8 & 0.51 & 0.49 \\
\hline $2006(21)$ & & Control & 28.8 & 42.4 & 28.8 & 0.50 & 0.50 \\
\hline Present & \multirow[t]{3}{*}{ Asian Indian } & Endometriosis & 4.5 & 29.09 & 66.36 & 0.20 & 0.80 \\
\hline \multirow[t]{2}{*}{ Study 2009} & & Uterine fibroids & 9.15 & 30.28 & 60.56 & 0.24 & 0.75 \\
\hline & & Control & 25.21 & 27.82 & 46.95 & 0.40 & 0.60 \\
\hline
\end{tabular}

ably the $\mathrm{ER} \alpha$ with $\mathrm{C}$ allele results in higher estrogen responsiveness of the receptor, this would result in enhanced estrogen mediated activities of cell proliferation and growth, promoting hyper estrogenic diseases like endometriosis and fibroids. Downstream genes of estrogen metabolism like vascular endothelial growth factor, endothelial nitric oxide synthase, etc., are also activated so as to promote cell survival and suppress apoptosis, which is characteristic of tumors. Functional studies on myometrial cell lines with different ER $\alpha$ genotypes to assess the proliferative response to estradiol has revealed that the cell lines with $\mathrm{ER} \alpha \mathrm{CC}$ genotype has significantly enhanced cell proliferation compared to cell lines with other $\mathrm{ER} \alpha$ genotypes indicating an in vivo correlation with hyper-estrogenic uterine diseases [20]. Further studies are needed in larger population to establish $\mathrm{ER} \alpha \mathrm{C}$ allele as a risk marker for endometriosis and fibroids in Asian Indian women. Ethnicity, race, diet etc may play a role in susceptibility to endometriosis and fibroids and further studies are warranted in this area. In conclusion, $\mathrm{ER} \alpha \mathrm{C}$ allele confers approximately 2 -fold increased risk of causing both endometriosis and fibroids, indicating that it can be considered risk marker in Asian Indian Women.

\section{Acknowledgements}

We would like to acknowledge ICMR (5/7/26/02RHN) and DBT (BT/PR/5516/MED/14 /646/2004) for the financial support provided to S.G and S.N. Thanks are due to the management and staff of Bhagwan Mahavir Medical Research Centre, Hyderabad, Govt. Maternity Hospital, Hyderabad and Durgabai Deshmukh Hospital, Hyderabad for providing clinical samples of the subjects enrolled in this study.

\section{References}

[1] A. Kauppila, P. Vierikko, H. Isotalo and L. Ronnemberg, Cytosol estrogen and progesterone receptor concentration and 
17-hydroxy steroid dehydrogenase activities in the endometrium and endometriotic tissue: effects of hormonal treatment, Acta Obstet Gynecol Scand (Suppl) 123 (1984), 45-52.

[2] T. Maruo, N. Ohara, J. Wang and H. Matsuo, Sex steroidal regulation of uterine leiomyoma growth and apoptosis, Hum Reprod Update 10 (2004), 207-220.

[3] L.A. Solomon, V.L. Schimp, R. Ali-Fehmi, M.P. Diamond and A.R. Munkarah, Clinical update of smooth muscle tumors of the uterus, J Minim Invasive Gynecol 12 (2005), 401-408.

[4] P.R. Koninckx, P. Ide and W. Vandenbroucke, New aspects of the pathophysiology of endometriosis ond associated infertility, J Reprod Med 24 (1980), 257-264.

[5] D.W. Cramer, E. Wilson, R.J. Stillman, M.J. Berger, S. Belisle, I. Schiff, B. Albrecht, M. Gibson, B.V. Stadel and S.C. Schoenbaum, The relation of endometriosis to menstrual characteristics, smoking and exercise, JAMA 25 (1986), 1904-1909.

[6] F. Chiaffarino, F. Parazzini, C. La Vecchia, E. Ricci and P.G. Crosignani, Oral contraceptive use and benign gynecologic conditions, Contraception 57 (1998), 11-18.

[7] P. Flake, J. Andersen and D. Dixon, Etiology and Pathogenesis of Uterine Leiomyomas: A Review, Environmental health perspectives 111(8) (2003), 1037-1054.

[8] A. Bergquist and M. Ferno, Oestrogen and progesterone receptors in endometriotic tissue and endometrium: comparison of different cycle phases and ages, Hum Reprod (8) (1993), 2211-2217.

[9] R.J. Howell, Dowsett and D.K. Edmonds, Oestrogens and progesterone receptors in endometriosis: heterogeneity of different sites, Hum Reprod 9 (1994), 1752-1758.

[10] R.K. Jones, J.N. Bulmer and R. Searle, Immunohistochemical characterization of proliferation, oestrogen receptor and progesterone receptor expression in endometriosis: comparison of eutopic and ectopic endometrium with normal cycling endometrium, Hum Reprod 10 (1995), 3272-3279.

[11] A.W. Brendenberger, D.I. Lebovic, M.K. Tee, I.T. Ryan, J.F. Seng, R.B. Jaffe and R.N. Taylor, Oestrogen receptor (ER)- alpha and ER-beta isoforms in normal endometrial and endometriosis-derived stromal cells, Mol Hum Reprod 5 (1999), 651-655.

[12] K.A. Kovacs, A. Oszter, P.M. Gocze, J.L. Kornyei and I. Szabo, Comparative analysis of cyclin D1 and Oestrogen receptor $(\alpha$ and $\beta$ ) levels in human leiomyoma and adjacent myometrium, Mol Hum Reprod 7 (2001), 1085-1091.

[13] F. Wieser, C. Schneeberger, D. Tong, C. Tempfer, J.C. Huber and R. Wenzl, PROGINS receptor gene polymorphism is associated with endometriosis, Fertil Steril 77 (2002), 309-312.

[14] Y.Y. Hsieh, Y.K. Wang, C.C. Chang and C.S. Lin, Estrogen receptor alpha-351 $\mathrm{XbaI}{ }^{*} \mathrm{G}$ and $-397 \mathrm{PvuII}{ }^{*} \mathrm{C}$-related genotypes and alleles are associated with higher susceptibilities of endometriosis and leiomyoma, Mol Hum Reprod 13 (2007), $117-122$.

[15] I. Georgiou, M. Syrrou, I. Bouba, N. Dalkalitsis, M. Paschopoulos, I. Navrozoglou and D. Lolis, Association of estrogen receptor gene polymorphisms with endometriosis, Fertil Steril 72 (1999), 164-166.

[16] S. An, E. Li and X. Tong, Study on relationship between estrogen receptor gene polymorphism and syndrome differentiation typing of female postmenopausal osteoporosis in Traditional Chinese medicine, Zhongguo Zhong Xi Yi Jie He Za Zhi 20(12) (2000), 907-910.

[17] J. Kitawaki, H. Obayashi, H. Ishihara, H. Koshiba, I. Kusuki, N. Kado, K. Tsukamoto, G. Hasegawa, N. Nakamura and H. Honjo, Oestrogen receptor-alpha gene polymorphism is as- sociated with endometriosis, adenomyosis and leiomyomata, Hum Reprod 16(1) (2001), 51-55.

[18] F. Massart, L. Bechenni, F. Marini, I. Noci, L. Piciocchi, F. Del Monte, L. Masi, A. Falchetti, A. Tanini, G. Scarsaelli and L. Brandi, Analysis of ER and PR polymorphism in uterine leiomyomata, Med Sci Monit 9 (2003), 25-30.

[19] Z. Wang, S. Yoshida, K. Negoro, S. Kennedy, D. Barlow and T. Maruo, Polymorphisms in the estrogen receptor beta gene but not estrogen receptor alpha gene affect the risk of developing endometriosis in a Japanese population, Fertil Steril 81(6) (2004), 1650-1656.

[20] A. Al-Hendy and S.A. Salama, Ethnic distribution of estrogen receptor-alpha polymorphism is associated with a higher prevalence of uterine leiomyomas in black Americans, Fertil Steril 86(3) (2006), 686-693.

[21] D. Denschlag, E.K. Bentz, L. Hefler, D. Pietrowski, R. Zeillinger, C. Tempfer and D. Tong, Genotype distribution of estrogen receptor-alpha, catechol-O-methyltransferase, and cytochrome $\mathrm{P} 45017$ gene polymorphisms in Caucasian women with uterine leiomyomas, Fertil Steril 85(2) (2006), 462 467.

[22] K. Neuss, D. Elling, I. Cascorbi and D. Lueftner, Association between breast cancer and estrogen receptor gene polymorphism PVU II, Journal of Clinical Oncology 24 (2006), 643.

[23] S.P. Renner, R. Strick, P. Oppelt, P.A. Fasching, S. Engel, R. Baumann, M.W. Beckmann and P.L. Strissel, Evaluation of clinical parameters and estrogen receptor alpha gene polymorphisms for patients with endometriosis, Reproduction 131 (2006), 153-161.

[24] S. Movva, R.V. Alluri, S. Komandur, K. Vattam, K. Eppa, K. Mukkavalid, S. Mubigondab, S. Saharia, J.C. Shastry and Q. Hasan, Relationship of angiotensin-converting enzyme gene polymorphism with nephropathy associated with Type 2 diabetes mellitus in Asian Indians, Journal of Diabetes and Its Complications 21 (2007), 237-241.

[25] S. Govindan, S.N. Ahmad, B. Vedicherla, V. Kodati, P. Jahan, K.P. Rao, Y.R. Ahuja and Q. Hasan, Association of Progesterone Receptor Gene Polymorphism (PROGINS) with Endometriosis, Uterine Fibroids and Breast Cancer, Cancer Biomarkers 3 (2007), 73-78.

[26] J.E. Girling and P.A. Rogers, Recent Advances in Endometrial Angiogenesis Research, Angiogenesis 8(2) (2005), 89-99.

[27] T. Collette, R. Maheux, J. Mailloux and A. Akoum, Increased Expression of Matrixmetalloproteinase-9 in the Eutopic Endometrial Tissue of Women With Endometriosis, Hum Reprod 21 (2006), 3059-3067.

[28] K.A. Babu, K.L. Rao, N.G. Reddy, M.K. Kanakavalli, K.T. Zondervan, M. Deenadayal, A. Singh, S. Shivaji and S. Kennedy, N-acetyl transferase 2 polymorphism and advanced stages of endometriosis in South Indian women, Reprod Biomed Online (2004), 533-540.

[29] K.A. Babu, N.G. Reddy, M. Deendayal, S. Kennedy and S. Shivaji, GSTM1, GSTT1 and CYP1A1 detoxification gene polymorphisms and their relationship with advanced stages of endometriosis in South Indian women, Pharmacogenet Genomics (2005), 167-172.

[30] M. Bhanoori, K.A. Babu, M. Deendayal, S. Kennedy and S. Shivaji, The interleukin-6 -174G/C promoter polymorphism is not associated with endometriosis in South Indian women, J Soc Gynecol Investig 12(5) (2005), 365-369.

[31] N.A. Shaik, S. Govindan, V. Kodati, K. Prabhakar Rao and Q. Hasan, Polymorphic (CAG)n repeats in the androgen receptor 
gene: a risk marker for endometriosis and uterine leiomyomas, Hematol Oncol Stem Cell Ther 2(1) (2009), 289-293.

[32] L. Yaich, W.D. Dupont, D.R. Cavener and F.F. Parl, Analysis of the PvulI Restriction Fragment Length Polymorphism and Exon Structure of the Estrogen Receptor Gene in Breast Cancer and Peripheral Blood, Cancer Research 52 (1992), $77-83$. 


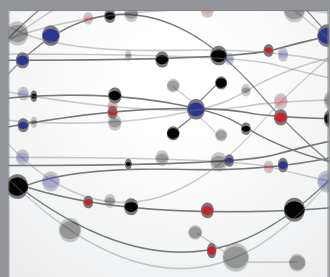

The Scientific World Journal
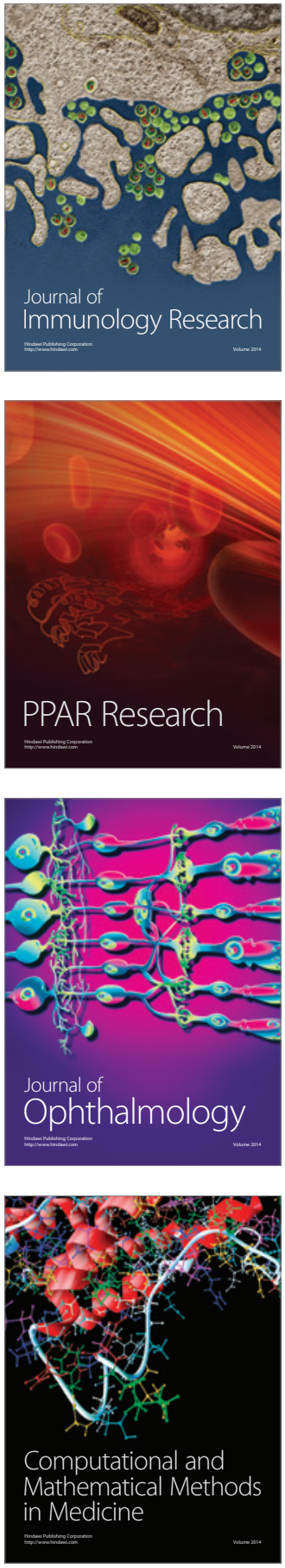

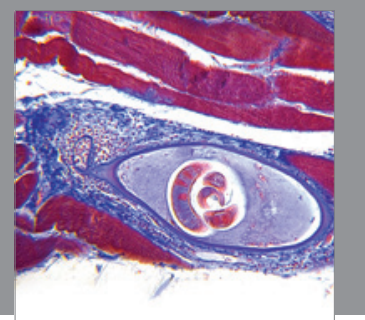

Gastroenterology

Research and Practice
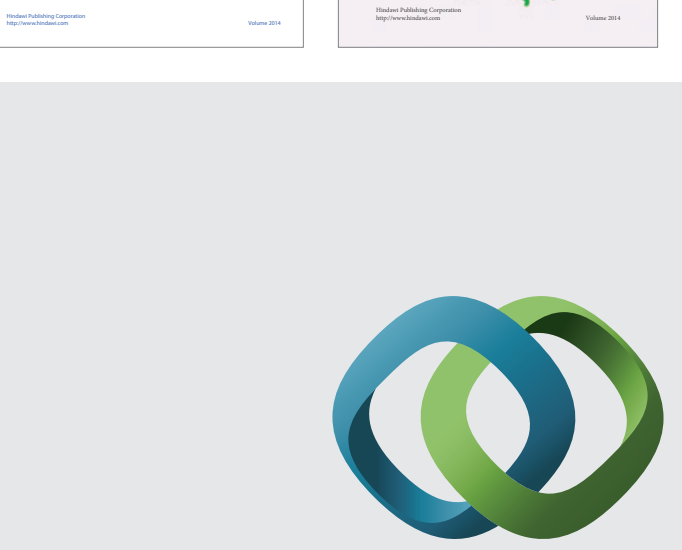

\section{Hindawi}

Submit your manuscripts at

http://www.hindawi.com
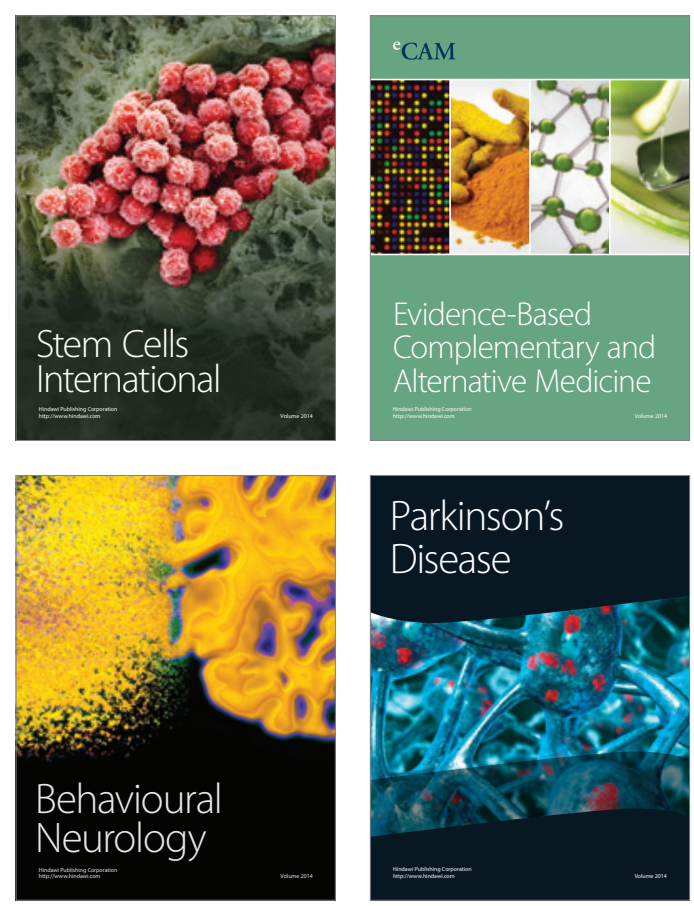

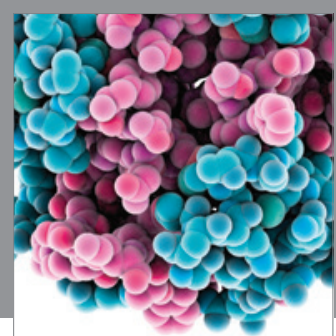

Journal of
Diabetes Research

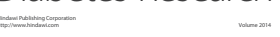

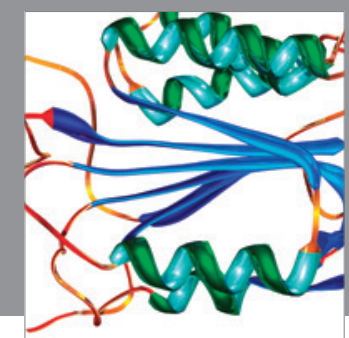

Disease Markers
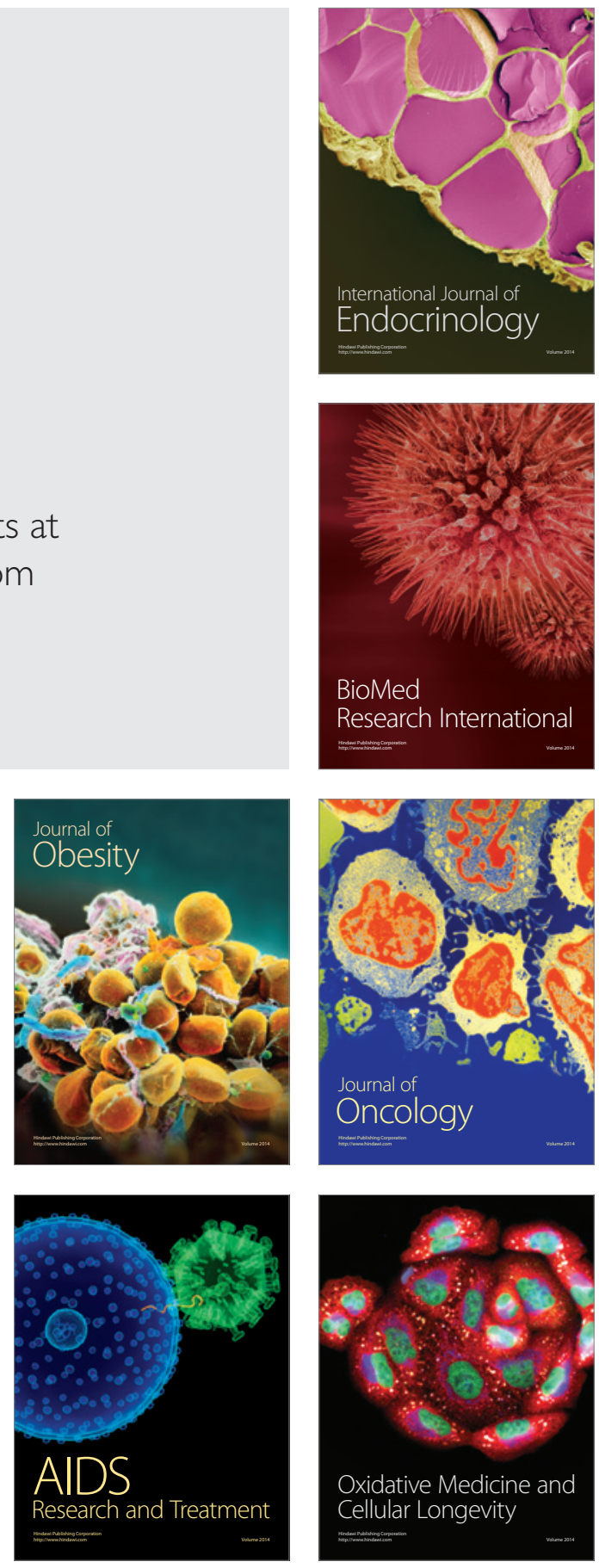